\title{
The Home Literacy Environments of Turkish Kindergarteners: Does SES Make a Difference? ${ }^{1}$
}

\section{Cevriye Ergül}

Assoc. Prof., Ankara University, Turkey, cergul@ankara.edu.tr

\section{Ayşe Dolunay Sarıca}

Asst. Prof., (corresponding author), Dokuz Eylül University, Turkey, dolunaysarica@gmail.com

\section{Gözde Akoğlu}

Assoc. Prof., Kırıkkale University, Turkey, gakoglu@kku.edu.tr

\section{Gökçe Karaman}

Dr., Ankara University, Turkey, gkaraman@ankara.edu.tr

This study investigated the possible differences in the home literacy environments (HLE) among Turkish kindergarteners from three different SES (socio-economic) strata. 341 parents of a total of 341 kindergarteners from 24 kindergarten classrooms in low, middle and high SES neighbourhoods across Ankara completed the Socio-Demographics Form and the Home Literacy Questionnaire (HLQ). Results of MANOVA and the Kruskal-Wallis test revealed significant differences among the three SES levels, with high SES scoring significantly higher than the middle and low SES and the middle SES scoring significantly higher than the low SES in all HLQ subscales. These findings imply that low and partly middle SES kindergarteners may be at a disadvantage for quality HLEs and so we educators have to look for ways to support these families. However results also point that all three groups fell within the "moderate HLE" range which shows that Turkish kindergarteners from all SES strata may need to be supported through systematic interventions.

Key Words: early literacy, home literacy environment, socio-economic status, kindergarten, home early literacy environment questionnaire

\footnotetext{
${ }^{1}$ This research was funded by Grant $111 \mathrm{~K} 161$ from the Scientific and Technological Research Council of Turkey (TUBITAK).
} 


\section{INTRODUCTION}

The first few years of elementary school are known to be critical for academic achievement throughout the school life. Reading and writing are two of the most important skills which a child is expected to accomplish during these early years (Fletcher \& Reese, 2005). Although earlier beliefs claimed that the beginning of reading was a formal school activity, today we have come to know that children process print long before the primary school years in their various social contexts, primarily in the home environment through observing and participating in daily literacy activities (Çakmak \& Yılmaz, 2009; Korat, 2005; van Steensel, 2006) as well as communicating with others using oral language (Rush, 1999).

The assumed link between being read to during the early years of life - a major home early literacy activity - and learning to read in the following elementary years (Huebner \& Payne, 2010; van Steensel, 2006), may be considered as a critical basis for investigating the home literacy activities parents provide to their preschoolers. Another major reason comes from studies claiming a one-to-one interaction, rather than a group activity, with an adult during early literacy activities being more effective on child early literacy and language performance (e.g., Lonigan \& Whitehurst, 1998). In addition, as Çakmak and Yılmaz (2009) claim, preschool and kindergarten, as well as other social settings are very important in building interest in print and reading but that it is the parents who are the first and most important providers of these social settings, therefore putting them in a very critical position in a child's early literacy experiences.

The environment within which early literacy activities take place, namely the Home Literacy Environment (HLE) is defined as "the environment the family provides the child to gain specific precursors of reading, writing and linguistic competencies" and includes both physical and social characteristics, with the physical environment containing the variety and availability of print materials for the child and the social environment involving child as well as adult-directed interactive literacy activities (Gonzales, Taylor et al., 2011; Payne, Whitehurst, \& Angell, 1994). The family is also responsible for providing rich experiences outside the home, which is also assumed to be important in developing early literacy skills (Çakmak \& Y1lmaz, 2009).

HLE is known to be closely related to several socio-demographic factors including child gender, family migration status and family SES - socio-economic status - (Karrass \& Braungart-Rieker, 2005; Niklas \& Schneider, 2013; Ren \& Hu, 2011; Silinskas, Lerkkanen, et al., 2012) where SES includes the structural characteristics of the family such as parent education and parent occupational status (Niklas \& Schneider, 2013). According to Gonzales and colleagues (2011) HLE can never be successful unless we take into account language and cultural differences among families. Thus SES may be considered as one of those static factors that influence the features of HLE for preschoolers. This potential relationship between the two constructs was never investigated in a Turkish population and this gap in the Turkish literature gave the authors of this study strong motivation to shed some light on this issue. 
Literature on early literacy mainly points to a significant relationship between SES and HLE. For example, Korat (2005) compared low and middle SES Israeli kindergarteners across two emergent literacy concepts - contextual knowledge (identification of reading and writing behaviour and reading environmental print) and non-contextual knowledge (phonological awareness, concepts about print and letter naming) - and their predictive value on emergent writing and word recognition. Results revealed that low SES children lagged behind their middle SES peers on non-contextual knowledge, while no significant differences were observed for contextual knowledge. The author claimed that these differences could most likely be explained by middle SES children being exposed more to literacy activities such as book reading by one of the parents on a daily basis, compared to their low SES peers (Korat, 2005), therefore putting low SES at risk for future reading difficulties.

Likewise, a longitudinal study on German children from the beginning of kindergarten through the end of the first grade revealed significant correlations for HLE with migration status and SES (Niklas \& Schneider, 2013). According to the findings, families with higher SES offered richer HLEs for their children and children with richer HLEs received higher scores on linguistic measures including phonological awareness, active vocabulary, and letter knowledge in both kindergarten and first grade. In addition, all precursors of reading competence predicted both reading and spelling at the end of the first grade. In light of these findings, Niklas and Schneider (2013) proposed a model of SES influencing HLE, HLE influencing the precursors of reading and spelling (phonological awareness, vocabulary and letter knowledge and non-specific precursors such as intelligence and rapid naming) and these in turn influencing reading and spelling competencies. This assumption is verified by other research findings, as well. For example Rush's (1999) study with low SES children revealed several associations between child literacy and vocabulary measures and the features of the care giving environments. Rush found that caregivers' active involvement (including child-directed speech) with their children during play, literacy and other daily activities was highly correlated with child's early literacy and language scores.

Another study with low SES children (Payne et al., 1994) investigated the relationship between HLE and child language scores and found that HLE accounted for 12\% (after the effects of caregiver IQ and education were removed in a hierarchical regression) and $18,5 \%$ (in simple correlation) of the variance in child language scores. The authors explained these relatively small percentages by a possible lack of taking into account other factors related to HLE that were not included in their study. Another finding showed low correlations between child language scores and adult-directed activities while high correlations were reported between child language scores and child-directed activities.

The match between child performance and parental evaluations of that performance is considered as an important element in many developmental domains and that there are variations among different SES families. To test this assumption on early literacy skills, Korat and Haglili (2007) investigated the relationships among actual child early literacy performance, maternal evaluations of child early literacy skills and parental mediations 
during an early literacy activity (shared book reading) between low and high SES Israeli families. Results showed that both high and low SES mothers overestimated their child's actual performance with low SES mothers showing significantly higher inaccuracies. In terms of maternal mediating scores during shared book reading, high SES mothers significantly scored higher than low SES mothers and only high SES mothers' mediation scores were highly positively correlated with child's early literacy performance. On behalf of these findings, the authors concluded that the rich socioeconomic context of a child's family may be affecting mothers' conceptions of their children's performance, which in turn reflects on maternal behaviours during early literacy activities and thus child performance. Therefore, since this formulation does not seem to work for low SES parents, these parents may require support for more accurate evaluations followed by more accurate expectations that may result in a better match between child performance and maternal supporting behaviours for early literacy.

A study using a web-based survey by Al Otaiba, Lewis, Whalon, Dyrlund, and McKenzie (2009) on HLE of children with Down syndrome also holds evidence for the possible association between parental education level (an important component in SES) and the richness of HLE. The study included parents with higher education levels compared to other studies and results showed that over $70 \%$ of the parents reported several literacy arrangements and activities including having more than 50 children's books in their homes, reading to their children on a daily basis and regular library visits. Many also reported that their children had reached many important literacy skills and that they held lifelong literacy goals for their children.

As far as HLE and SES are concerned, there is also another issue to be tackled. Although the literature cited above shows that low SES seems to be a risk factor for HLE and therefore early literacy skills of children, Payne and colleagues (1994) state that there are also variations in the quality of HLE among low SES families. The researchers stress the fact that, despite many economic burdens upon the family, many low SES families put effort in interacting with their children for literacy support through, for example shared book reading. van Steensel's (2006) work in Netherlands holds evidence for this assumption, emphasizing the fact that families in all SES strata (determined by maternal education in the study), one way or another put effort in supporting their children's formal literacy skills; where low SES families prefer childdirected activities while high SES prefer both child-directed and personal literacy activities. Findings showed that parental modelling did make a difference for vocabulary scores in first grade and reading comprehension in first and second grades, but not for word decoding and spelling. van Steensel (2006) claimed that skills such as spelling and word decoding are learned by children from all SES backgrounds and HLEs through formal instruction at school, while child and adult-directed activities practiced in rich HLE families make a difference on vocabulary and reading comprehension in early primary school years. Despite this, van Steensel (2006) argued that literacy development in early primary school years is not determined only by HLE but also by other factors such as child participation in preschool education and formal instruction in primary school. 
HLE is a fairly new topic of interest in Turkey, where the authors of this article were able to reach only three studies, with only one study by Çakmak and Yılmaz (2009) dealing directly with HLE. Çakmak and Yllmaz (2009) investigated the relationship between interest in books and HLE among 50 middle and high SES kindergarteners and found that rich HLEs resulted in increased interest in print materials and reading behaviours. Findings from semi-structured interviews with the children showed that with the exception of "library visits", families provided child and parent-directed literacy activities on a daily basis while informal tests on reading interest revealed high interest on behalf of the children. These findings may not be surprising to the reader, since these children come mostly from middle to high SES backgrounds.

The remaining two studies were more involved with school readiness levels of Turkish kindergarteners, however showing indirect evidence in HLE and SES relationships. Erkan's (2011) study on the school readiness levels of first graders from low and high SES families included measures for certain early literacy skills including phonological awareness, listening comprehension and letter-sound relations and found that children in the high SES group scored significantly higher on all measures compared to low SES first graders. She also reported findings regarding a significant relationship between maternal education and school readiness scores in both SES groups, where children of mothers with a high school or a university degree had higher school readiness scores than children of mothers with lower education levels. Parallel with the postulation made by Niklas and Schneider's (2013), Erkan's study gives an idea on the possible effects of SES (in this case, maternal education) on HLE and early literacy skills. However, one should note that the results point only to indirect evidence leaving out HLE from the equation.

The second study on school readiness by Yangin (2009) showed that school readiness, letter-sound relations and phonemic awareness scores of the first graders measured at the beginning of the school year had predictive values on reading and writing performance at different periods during the same school year. Yangin reported that all three measures together accounted for $37 \%$ of the variance for reading and $35 \%$ for writing performance but that only school readiness was a significant predictor of the dependent variables. The author stated that the school readiness measure used in her study included cognitive and language skills only and that child factors such as health, social development and enthusiasm are measured within school readiness in future studies.

Taken together, the relationship between SES and HLE in preschool children may be a much more complex issue than we believe but we may conclude that these concepts are somehow importantly related. Looking at previous research, it seems difficult to come up with definite answers to these issues, especially for a totally different - in this case the Turkish - culture where very limited studies to date have been conducted. Therefore the aim of this study was to investigate the relationship between SES and HLEs of Turkish kindergarteners. In order to feed our discussion on the possible differences among the SES groups, we also intended to investigate the quality of the home literacy environment based on the normative scores resulting in three distinct categories (poor, 
moderate, high) obtained by Sarıca, Ergül and colleagues (2014). Therefore the research questions were as follows:

1. What are the group differences on the HLQ Reading Subscale scores of parents of kindergarteners from low, middle and high SES strata?

2. What are the group differences on the HLQ Writing Subscale scores of parents of kindergarteners from low, middle and high SES strata?

3. What are the group differences on the HLQ Phonological and Print Awareness Subscale scores of parents of kindergarteners from low, middle and high SES strata?

4. What are the group differences on the HLQ Shared Book Reading Subscale scores of parents of kindergarteners from low, middle and high SES strata?

5. Which category (poor, moderate, rich home literacy environment) do the HLQ subscale scores fall within for the low, middle and high SES groups?

\section{METHOD}

\section{Research Design}

The home literacy environments of preschoolers are a fairly new topic of interest in Turkey and no studies to date have tempted to describe these environments across important child and/or family variables. This study was designed as a descriptive survey study aiming at comparing the HLEs of kindergarteners from different SES strata, an important family component in child development.

\section{Sample}

The sample consisted of 350 parents of a total of 350 children attending 24 kindergarten classrooms in 12 elementary schools (of which 4 were located in low, 4 in middle and 4 in high SES neighbourhoods) across Ankara, the capital of Turkey. The schools were randomly selected across 3 school districts. 341 parents returned the SocioDemographics Form and the Home Literacy Questionnaire, with a $97.4 \%$ return rate. For each child, one of the parents in the household was asked to complete the questionnaire. 56.6\% $(n=193)$ of the children were girls while $43.4 \%(n=148)$ were boys and $173(\% 50.7)$ children had some nursery or day care history for at least 1 year prior to kindergarten. Parents' average age were $33.46(\mathrm{sd}=5.31$, range $=22-58)$ for mothers and $37.5(\mathrm{sd}=5.65$, range $=24-60)$ for fathers. Data on maternal education showed that $1.2 \%(\mathrm{n}=4)$ were either illiterate or had left elementary school, $28 \%(\mathrm{n}=95)$ graduated from primary school, 27.9\% ( $\mathrm{n}=95)$ from high school, $32.9 \%(\mathrm{n}=105)$ from an undergraduate program and $12.1 \%(\mathrm{n}=41)$ from a graduate program. The numbers for paternal education were $0.3 \%(\mathrm{n}=1), 23.9 \%(\mathrm{n}=81), 30.1 \%(\mathrm{n}=102), 31 \%(\mathrm{n}=105)$ and $14.7 \%(\mathrm{n}=50)$, respectively.

Due to the fact that a quite number of participants left the "family monthly income" column blank and that SES includes other factors such as parent education and parent occupational status (see Niklas \& Schneider, 2013), the authors formed an SES Index for the participants, taking into account parent education and occupational status, child 
having a private room of her own and family monthly income. Based on this SES Index, of the 341 participants $37.8 \%(n=129)$ were in the high SES, 28.4\% ( $n=97)$ in the middle SES and $33.7 \%(n=115)$ were in the low SES group.

\section{Procedure}

With the official permission of the Turkish Ministry of Education, 12 schools from 3 school districts across Ankara were chosen randomly to take part of the study. The school administrators and teachers were contacted and informed of the study during the 2011-2012 school year. The teachers were asked to send the data collection instruments to parents of their students and request the forms back within a week.

\section{Measures}

The Socio-Demographics Form. A demographic form was developed by the researchers to gather information on child, parent and family demographics. Items on this form include child age, gender and day care experience, parent education, parent occupational status and family monthly income.

The Home Early Literacy Environment Questionnaire (HLQ). The Home Early Literacy Environment Questionnaire-HLQ was used to measure the home literacy environments of the participants' children. The HLQ was developed by Sarıca and colleagues (2014) in order to collect information on the home literacy environments of Turkish kindergarteners. The questionnaire includes 23 items under 4 factors; Reading, Writing, Phonological and Print Awareness and Shared Book Reading, with child-directed as well as parent-directed home literacy behaviours. Table 1 includes some exemplary items from each subscale.

Table 1

Exemplary Items from HLQ

\begin{tabular}{ll}
\hline Subscale & Item \\
\hline \multirow{2}{*}{ Reading } & $\begin{array}{l}\text { When did you begin reading to your child? } \\
\text { How many books does your child have of her own? }\end{array}$ \\
\hline \multirow{2}{*}{ Writing } & $\begin{array}{l}\text { How often does your child write words? } \\
\text { How often does your child ask you to write something for her? }\end{array}$ \\
\hline \multirow{2}{*}{$\begin{array}{l}\text { Phonological and Print } \\
\text { Awareness }\end{array}$} & $\begin{array}{l}\text { How often do you teach your child the letters of the alphabet? } \\
\text { How often does your child ask for your assistance in reading } \\
\text { words on food packages or traffic signs? }\end{array}$ \\
\hline \multirow{2}{*}{ Shared Book Reading } & $\begin{array}{l}\text { How often does your child ask questions on the characters or } \\
\text { events in the story? }\end{array}$ \\
\hline
\end{tabular}

A high score on HLQ points to a rich HLE for the child. The exploratory and confirmatory factor analyses and the Cronbach Alpha estimates for each subscale display promising evidence for the questionnaire's reliability and validity. On a Turkish sample of 341 parents of kindergarteners, the exploratory factor analysis results showed that the four subscales explained $54.81 \%$ of the variance of the scores with relatively high Cronbach Alpha estimates (.84, .84, .77 and .70 for the Reading, Writing, Phonological and Print Awareness and Shared Book Reading subscales, respectively) 
while the goodness of fit indices for the HLQ were as follows: RMSEA=.09, GFI=.81, $\mathrm{CFI}=.92, \mathrm{AGFI}=.76, \mathrm{NNFI}=.91$.

\section{FINDINGS}

All analyses were performed using SPSS 17.0 for Windows statistical program. Firstly, the homogeneity of variances was tested via Levene's test, where the assumption of homogeneity was supported for all subscales but Phonological and Print Awareness. Thus a one-way multivariate analysis of variance (MANOVA) was conducted to determine the effect of SES on the three HLQ subscales (Reading, Writing and Shared Book Reading) and Kruskal-Wallis nonparametric test on the Phonological and Print Awareness subscale.

\section{Findings Regarding the HLQ Subscales}

The descriptive statistics and the results of MANOVA for the three subscales are displayed in Table 2.

Table 2

Descriptive Statistics and Results for the Three HLQ Subscales

\begin{tabular}{lllllcccc}
\hline \multirow{6}{*}{ Reading } & $\begin{array}{l}\text { Group } \\
\text { (SES) }\end{array}$ & $N$ & Mean & sd & $F$ & $p$ & $\eta^{2}$ & $\begin{array}{c}\text { Post } \\
\text { hoc }\end{array}$ \\
& Low & 113 & 21.76 & 3.23 & & & & \\
& Middle & 90 & 26.00 & 3.50 & 139.81 & $0.000^{*}$ & 0.51 & $\mathrm{~L}<\mathrm{M}$ \\
& High & 106 & 29.49 & 3.06 & & & & $\mathrm{M}<\mathrm{H}$ \\
& Total & 309 & 25.57 & 4.65 & & & & \\
\hline \multirow{5}{*}{ Writing } & Low & 126 & 14.83 & 4.99 & & & & $\mathrm{~L}<\mathrm{M}$ \\
& Middle & 90 & 16.93 & 5.62 & 14.96 & $0.000^{*}$ & 0.22 & $\mathrm{M}<\mathrm{H}$ \\
& High & 112 & 18.83 & 4.90 & & & & \\
\hline \multirow{2}{*}{ Shared } & Total & 328 & 16.64 & 5.40 & & & & \\
Book & Low & 115 & 12.48 & 3.05 & & & \\
Reading & Middle & 86 & 14.89 & 3.13 & 38.52 & $0.000^{*}$ & 0.10 & $\mathrm{~L}<\mathrm{M}$ \\
& High & 110 & 16.08 & 2.61 & & & & $\mathrm{M}$ \\
\hline
\end{tabular}

$* \mathrm{p}<0.001$

The results of MANOVA showed significant differences among the SES levels on the dependent measures $(\lambda=0.472 ; F(6,540)=40.95 ; p<.001)$. The multivariate $\eta^{2}$ based on Wilks's $\lambda(.47)$ was found to be quite strong. Follow up analyses of variances (ANOVA) for each subscale showed significant differences across SES levels [Reading ( $F(2$, $309)=139.81 ; p<.001)$, Writing $(F(2,328)=14.96 ; p<.001)$ and Shared Book Reading $(F(2,311)=38.52 ; p<.001)]$. The results pointed to high effect sizes for the Reading and Shared Book Reading subscales $\left(\eta^{2}=0.51\right.$ for Reading and $\eta^{2}=0.22$ for Shared Book Reading) while for Writing, the effect size was moderate $\left(\eta^{2}=0.10\right)$. The post hoc comparisons following the ANOVAs yielded significant differences for all paired SES groups. That is, for each subscale, the high SES group scored significantly higher than the middle SES and the middle SES scored significantly higher than the low SES group (see Table 2). 
Due to lack of homogeneity of variances, the Kruskal-Wallis nonparametric test was conducted for the Phonological and Print Awareness subscale. According to the results, the highest mean belonged to the high SES group $(X=17.90)$, followed by middle SES $(X=16.20)$ and low SES groups $(X=14.16)$ and the Kruskal-Wallis test yielded significant differences among these groups $\left(\chi^{2}(2,303)=25.20 ; p<.05\right)$. We used a MannWhitney-U test following this procedure to investigate the differing group pairs. Results showed that the middle SES group scored significantly higher than the low SES group $(U=3745.50, p<.05)$ while the high SES group scored significantly higher than both the low $(U=3682.5, p<.01)$ and the middle SES groups $(U=3600, p<.05)$, a finding parallel to the results of MANOVA for the remaining three subscales.

In sum, the scores obtained by the participants from all HLQ subscales showed that SES and HLE were significantly related with kindergarteners coming from high SES backgrounds being advantageous in terms of a richer home literacy environment compared to kindergarteners from lower SES strata followed by middle SES kindergarteners compared to low SES kindergarteners.

\section{Findings Regarding the Quality of the Home Literacy Environment}

In addition, we wanted to investigate the quality of the home literacy environment for each SES group fell on all four HLQ subscales. Table 3 shows the normative ranges for poor, moderate and rich HLEs.

Table 3

Home Literacy Environment Normative Scores for the HLQ Subscales*

\begin{tabular}{lccc}
\hline \multirow{2}{*}{ Subscale } & \multicolumn{3}{c}{ Normative scores for HLE categories } \\
\cline { 2 - 4 } & Poor & Moderate & Rich \\
\hline Reading & $8-20,90$ & $20.91-30.23$ & $30,24-39$ \\
\hline Writing & $5-11,23$ & $11.24-22.04$ & $22,05-25$ \\
\hline Phonological and Print Awareness & $6-10,95$ & $10.96-21.08$ & $21,09-30$ \\
\hline Shared Book Reading & $4-10,98$ & $10.99-17.77$ & $17,78-20$ \\
\hline * & & &
\end{tabular}

* Data taken from Sarica and colleagues (2014)

According to the norm values reported by Sarica and colleagues (2014), all SES groups fell within the "moderate HLE" range on all HLQ subscales (see Table 2 for mean scores for each SES group). However, it should be noted that the high SES group scored very close to the "rich HLE" category on all four subscales.

\section{DISCUSSION}

The quality and quantity of children's early social experiences may be considered to play an important role in explaining the disparity in the school achievement of children from different SES backgrounds (Rush, 1999). This study found differences in the HLE of children across different SES backgrounds and our findings can be considered to be important in several ways.

As far as early literacy support for children is concerned, a focus on SES as the primary variable in this study was thought to be critical for Turkish kindergarteners, since a basic assumption exists on SES influencing HLE and this in turn affecting the early literacy 
skills of kindergarteners (Niklas \& Schneider, 2013). Surely, it is almost impossible for us as educators to change a family's SES, whether it is income, parent occupation or the number of rooms in the house. However, partly knowing by the results of our study as well as others (Erkan, 2011; Korat, 2005; Lam, Chow-Yeung, Wong, Lau, \& Tse, 2012; Niklas \& Schneider, 2013), we may assume the risks for children in low and middle SES families and therefore attempt to change these children's HLEs through parent education and/or home visits. Nevertheless, we have to keep in mind that enhancing the HLEs of low SES families requires targeting the forms of behaviour that can only be feasible within an environment of poverty.

According to Huebner and Payne (2010), parents' beliefs about the early literacy development of their children is an important indicator of the home literacy activities they provide for them. The results of this study show that children of low SES families may be at a disadvantage for HLE, with the assumption that these families are not thoroughly informed on the benefits of providing rich HLEs for their children. If this is true, perhaps we may claim that early intervention would be advisable in families who provide poor literacy environments for their children, in this case ones within the low SES range.

An important issue to be considered at this point is whether the high SES families' HLE scores in our sample are within the "rich HLE" range or not. Looking back at the average scores of each SES group, despite the significant differences among the three SES groups in favour of high SES on all four factors, these scores in each SES group fell within the "moderate HLE" range reported by Sarıca and colleagues (2014). Therefore, we can conclude that, as in low SES families, Turkish middle and high SES families do not seem to provide rich HLEs for their children as well. Nevertheless, when the high SES mean scores are examined once again, one may notice that they are at the upper limit within the "moderate HLE" range.

This finding supports the view that early literacy skills of children from all socioeconomic strata should be supported through systematic interventions (Huebner \& Payne, 1994). Lam and colleagues (2012) for example, showed that the effects of their paired reading program were alike in both low and high SES families, in terms of child, parent and parent-child interaction outcomes. Although the authors measured SES based solely on family income, they believed that this may not be considered disappointing such that it actually may have a cautioning effect on educators who believe that high SES families know more than lower SES families. This seems to fit with our findings and despite the fact that low SES children are at a higher risk for early and therefore formal literacy, we as Turkish educators need to look for ways to support children from all SES backgrounds.

Speaking of early literacy intervention, ours as well as others' works (Ortiz, Stowe, \& Arnold, 2001; Payne et al., 1994) do not tell us whether quality or quantity is important in child performance in low and middle SES families. Put another way, if all we have to do is to increase the time of early literacy activities to increase child's early literacy performance, and then a systematic intervention may not be necessary. However, studies like Silinskas and colleagues' (2012) point to the importance of identifying the 
qualitative nature of formal and informal reading-related activities in the home environment before jumping into any conclusions. Therefore, future studies may be required to focus on the qualitative differences across SES levels and shape interventions accordingly.

Perhaps one such qualitative parental factor that needs further investigation in Turkish kindergarteners is parental evaluations of the literacy development of children. Korat and Haglili (2007) had found relationships among maternal evaluations on early literacy skills of their children, actual child performance and maternal mediations in parent-child book reading, where high SES mothers had more accurate evaluations of their child's actual performance, related with higher level mediations. It may be that low and partially middle SES parents require an education where they are taught to read their children's skill levels more accurately and get involved in activities that fit with the child's skill level.

In the Turkish culture, many more factors need further investigation as well. First of all, we need to look into general parental attitudes toward interest in reading, which can be said to form the basis for child and parent-directed literacy routines in the home environment. The authors' experience in this issue shows that an average Turkish family's interest in literacy activities is fairly limited. Secondly, the nation's educational policies and how these policies are reflected in preschool and kindergarten classrooms need detailed investigation so that we may get the big picture concerning what children are going through within formal education in terms of school readiness. In the Turkish educational system, activities involving the precursors of reading and writing include concept development, print awareness, holding a pencil, writing numbers and building a positive attitude toward reading (MEB, 2013). However, they are outnumbered by other skills in the preschool and kindergarten curriculum and pre-service as well as in-service teachers who are discouraged for arranging activities that include reading and writing instruction. Therefore, Turkish kindergarteners, including all from different SES backgrounds may be at risk for early literacy support both at home as well as the school environment. We believe that this assumption definitely needs further investigation.

One major limitation of this study was that it was taking into account only one family variable, SES, which was assumed to be associated with HLE. However, according to other researchers, one must also consider the differences in home literacy environments across families in the same SES. Rush's (1999) findings on some children's language and early literacy performance in her low SES sample which is within the range of normal development and Payne and colleagues' (1994) study with low SES families reporting qualitative differences in HLE (e.g. preference for child-directed compared to parent-directed activities) related to child language are some examples for this argument. In their study, Payne and colleagues (1994) strongly emphasize that despite certain financial stresses in low SES families, these families may well be putting effort in interacting with their children for literacy development. Similarly, Ren and Hu (2011) point out that families within the same SES level may handle their financial and social resources for their children's development and education very differently, resulting in varying and sometimes unexpectedly poor or rich home literacy environments. 
Ortiz and colleagues' (2001) explanation may perhaps lighten this issue. In their experimental study, the researchers claimed that the only most important factor in raising child interest in early literacy activities may be to match parent behaviours with child interest, no matter how it is created. This raises the question of individualized interventions for parent-child early literacy interventions. Related with the findings of our study, although we found SES to be related with HLE, we strongly recommend individual observations and interventions for each family.

Dolezal-Sams, Nordquist, and Twardosz's (2009) study also adds up to our knowledge on individual differences across families with similar SES backgrounds. In their study including 6 middle SES families with children with developmental delays, Dolezal-Sams and colleagues investigated the possible link between the physical, social and symbolic (community and cultural influences) resources of families and their adult-child book reading activities and brought out the similarities and differences in family resources. Some of the major findings in their study included the close relationship between daily shared book reading and predictable daily routines, presence and accessibility of print materials in the home, routine library visits and support from friends and extended family members. These factors may be achieved among many families from different SES backgrounds and children may be affected in similarly positive ways. Therefore we must accept the fact that home literacy environments of children with similar as well as different SES backgrounds may well be more different than alike. This condition caused to a call for HLE and early literacy research simultaneously taking into account the many social and physical factors which families face in their everyday lives (Erkan, 2011; Payne et al., 1994; van Steensel, 2006). Within this viewpoint, we recommend the collection of qualitative besides quantitative data from several sources including family socio-demographics, home and classroom observations, parent, teacher and child interviews and portfolios.

This study was designed as a descriptive survey, including only parental reports on the HLE of their kindergarteners. Despite the important implications based on the findings, child outcomes and their relation to SES or other factors are needed before sound conclusions can be made. Therefore, the next step should be to conduct longitudinal studies investigating the effects of HLE on child early as well as formal literacy performance with children from different SES strata on elementary school achievement.

Coming back to our research question "Does SES make a difference?", we may claim that the answer is "Yes". However, we are aware that this is the single study relating SES to HLE in only one of the metropolitans in Turkey and we support the idea that similar studies in different suburban and rural areas across the nation should be conducted before we begin to test systematic interventions for kindergarteners from different SES strata.

\section{REFERENCES}

Al Otaiba, S., Lewis, S., Whalon, K., Dyrlund A., \& McKenzie, A. R. (2009). Home literacy environments of young children with Down syndrome: Findings from a webbased survey. Remedial and Special Education, 30, 96-107. 
Çakmak, T., \& Yılmaz, B. (2009). A research about the reading habit readiness situations of preschool children: Hacettepe University Beytepe Preschool sample. Türk Kütüphaneciliği, 23, 489-509.

Dolezal-Sams, J. M., Nordquist, V. M., \& Twardosz, S. (2009). Home environment and family resources to support literacy interaction: Examples from families of children with disabilities. Early Education and Development, 20, 603-630.

Erkan, S. (2011). A study on the school readiness of first graders from different socioeconomic levels. Hacettepe University Journal of Education, 40, 186-197.

Fletcher, K. L., \& Reese, E. (2005). Picture book reading with young children: A conceptual framework. Developmental Review, 25, 64-103.

Gonzales, J. E., Taylor, A. B., McCormick, A. S., Villareal, V., Kim, M., Perez, E., Darensbourg, A., \& Haynes, R. (2011). Exploring the underlying factor structure of the home literacy environment (HLE) in the English and Spanish versions of the Familia Inventory: A cautionary tale. Early Childhood Research Quarterly, 26, 475-483.

Huebner, C. E., \& Payne, K. (2010). Home support for emergent literacy: Follow-up of a community-based implementation of dialogic reading. Journal of Applied Developmental Psychology, 31, 195-201.

Karrass, J., \& Braungart-Rieker, J. M. (2005). Effects of shared parent-infant book reading on early language acquisition. Applied Developmental Psychology, 26, 133-148.

Korat, O. (2005). Contextual and non-contextual knowledge in emergent literacy development: A comparison between children from low SES and middle SES communities. Early Childhood Research Quarterly, 20, 220-238.

Korat, O., \& Haglili, S. (2007). Maternal evaluations of children's emergent literacy level, maternal mediation in book reading and children's emergent literacy level: A comparison between SES groups. Journal of Literacy Research, 39, 249-276.

Lam, S. F., Chow-Yeung, K., Wong, B. P. H., Lau, K. K., Tse, S. I. (2012). Involving parents in paired reading with preschoolers: Results from a randomized controlled trial. Contemporary Educational Psychology, doi: http://dx.doi.org/10.1016/j.cedpsych.2012.12.003

Lonigan, C. J., \& Whitehurst, G. J. (1998). Relative efficacy of parent and teacher involvement in a shared-reading intervention for preschool children from low-income backgrounds. Early Childhood Research Quarterly, 13, 263-290.

MEB (2013). Okul öncesi eğitim programı [Preschool education curriculum]. Retrieved October 11, 2013 from: http://ttkb.meb.gov.tr/program2.aspx?islem=1\&kno=202

Niklas, F., \& Schneider, W. (2013). Home literacy environment and the beginning of reading and spelling. Contemporary Educational Psychology, 38, 40-50.

Ortiz, C., Stowe, R. M., \& Arnold, D. H. (2001). Parental influence on child interest in shared picture book reading. Early Childhood Research Quarterly, 16, 263-281. 
Payne, A. C., Whitehurst, G. J., \& Angell, A. L. (1994). The role of home literacy environment in the development of language ability in preschool children from lowincome families. Early Childhood Research Quarterly, 9, 427-440.

Ren, L., \& Hu, G. (2011). A comparative study of family social capital and literacy practices in Singapore. Journal of Early Childhood Literacy, 13, 98-130.

Rush, K. L. (1999). Caregiver-child interactions and early literacy development of preschool children from low income environments. Topics in Early Childhood Special Education, 19, 3-14.

Sarıca, A. D., Ergül, C., Akoğlu, G., Deniz, K. Z., Karaman, G., Bahap-Kudret, Z., \& Tufan, M. (2014). The reliability and validity of the Home Early Literacy Environment Questionnaire. International Online Journal of Educational Sciences, 6, 444-459.

Silinskas, G., Lerkkanen, M. K., Tolvanen, A., Niemi, P., Poikkeus, A. M., \& Nurmi, J. E. (2012). The frequency of parents' reading-related activities at home and children's reading skills during kindergarten and grade 1. Journal of Applied Developmental Psychology, 33, 302-310.

van Steensel, R. (2006). Relations between socio-cultural factors, the home literacy environment and children's literacy development in the first years of primary education. Journal of Research in Reading, 29, 367-382.

Yangin, B. (2009). The relationship between readiness and reading and writing performances. Hacettepe University Journal of Education, 36, 316-326.

\section{Turkish Abstract \\ Türk Anaokulu Öğrencilerinin Ev Okur-Yazarlık Ortamları: Sosyo Ekonomik Düzeyler Farklılık Yaratır mı?}

$\mathrm{Bu}$ çalışma 3 farklı sosyo-ekonomik düzeyden seçilen Türk anasınıfı öğrencilerinin ev okuryazarlık ortamlarındaki olası farklılıkları incelemiştir. Ankara genelinde düşük, orta ve yüksek sosyo- ekonomik düzeye ait 24 farklı anasınıfından seçilen toplam 341 anasınıfı öğrencisi ve onların aileleri, sosyo demografik özellikler formu ve ev okur-yazarlık ölçeğini doldurmuşlardır. MANOVA ve Kruskal-Wallis test sonuçları 3 sosyo-ekonomik düzeye ait aileler arasındaki ev okur-yazarlık seviyelerinin anlamlı derecede farklılık görülmüş, yüksek sosyoekonomik düzeye ait sonuçların orta ve düşük düzeylerden anlamlı bir şekilde yüksek çıktığı; orta sosyo ekonomik düzeye ait sonuçların düşük düzeylerden anlamlı bir şekilde yüksek çıktığı gözlenmiştir. Bulgular, düşük ve kısmen orta sosyo ekonomik düzeye sahip anaokulu öğrencilerinin kaliteli ev okur-yazarlık ortamları konusunda dezavantajlı olduğunu ve eğitimciler olarak bizlerin bu aileleri desteklemek için çözüm yolları aramamız gerektiğini göstermiştir. Bununla beraber sonuçlar bütün gruplardaki 11 เmlı ev okur-yazarlık ortamı oranının düşük olmasının ailesinin sosyo-ekonomik düzeyi ne olursa olsun bütün anaokulu öğrencilerinin sistematik müdehalelere ihtiyaç duyabileceğini göstermiştir.

Anahtar Kelimeler: erken okur-yazarlık, ev okur-yazarlık ortamı, sosyo ekonomik düzey, anaokulu, ev erken okur-yazarlik ortami ölçeği 


\section{French Abstract}

Les Environnements d'Alphabétisation Domestiques de Kindergarteners turc: SES Fait-il une Différence?

Cette étude a examiné les différences possibles des environnements d'alphabétisation domestiques (HLE) parmi kindergarteners turc de trois strates (socio-économiques) SES différentes. 341 parents d'un total de 341 kindergarteners de 24 salles de classe de maternelle dans des voisinages SES bas, moyens et hauts à travers Ankara ont complete la Forme de Socio-donnéesdémographiques et le Questionnaire d'Alphabétisation Domestique (HLQ). Les résultats de MANOVA et le test de Kruskal-Wallis ont révélé que des différences significatives parmi trois SES se nivellent, avec haut SES marquant significativement plus haut que le milieu et bas SES et le milieu SES marquant significativement plus haut que SES bas dans toute la sous-balance HLQ. Ces découvertes impliquent que bas et en partie le milieu SES kindergarteners peut être à un inconvénient pour la qualité des HL et que nous les éducateurs doivent chercher des façons de supporter ces familles. Cependant les résultats le dirigent aussi tous les trois groupes sont tombés dans "HLE modéré" la gamme qui montre que kindergarteners turc de toutes les strates SES peut devoir être supporté par des interventions systématiques.

Mots Clés: première alphabétisation, environnement d'alphabétisation domestique, statut socioéconomique, jardin d'enfants (maternelle), à la maison premier questionnaire d'environnement d'alphabétisation

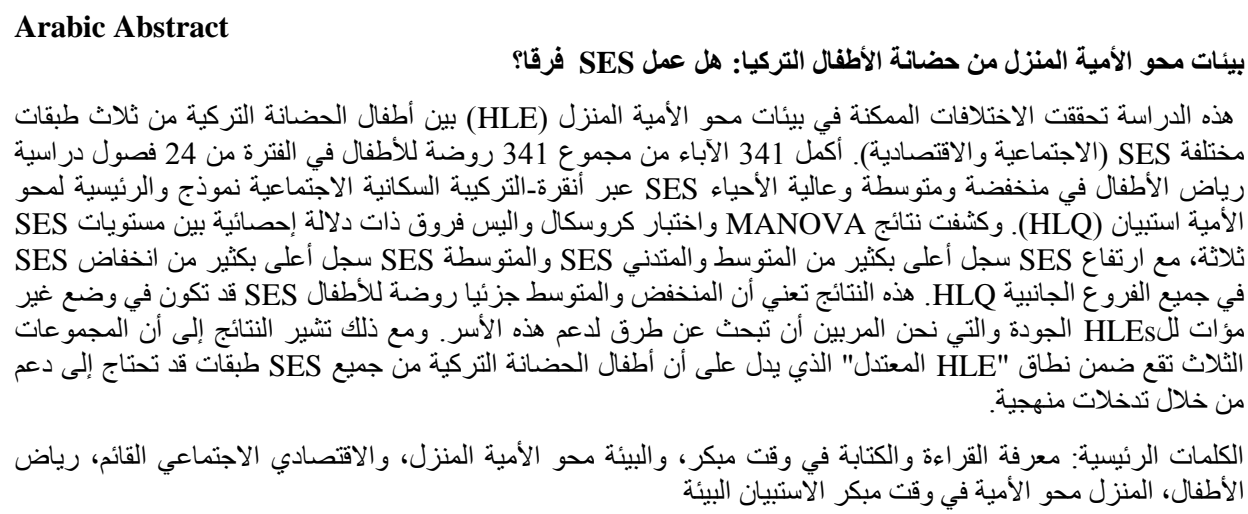

\section{German Abstract}

Die Heimat-Alphabetisierungsumgebung türkischer Kindergärtner: Macht SES einen Unterschied?

Diese Studie untersuchte die möglichen Unterschiede in den HeimatAlphabetisierungsumgebungen (HAU) unter den türkischen Kindergärtnern aus drei verschiedenen SES- (sozioökonomischen) Schichten. 341 Kindergartenkinder aus 24 Kindergarten-Klassenräumen in niedrigen, mittleren und hohen SES-Nachbarschaften in Ankara vervollständigten die Socio-Demographische Form und den Heimat-Alphabetisierungsfragebogen (HLQ). Ergebnisse von MANOVA und dem Kruskal-Wallis-Test zeigten signifikante Unterschiede zwischen den drei SES-Ebenen, wobei hohe SES-Werte signifikant höher waren als die mittleren und niedrigen SES und das mittlere SES-Scoring signifikant höher als das niedrige SES in allen HLQ-Subskalen. Diese Ergebnisse deuten darauf hin, dass niedrige und teilweise mittlere SES-Kindergärtner nachteilig für qualitativ hochwertige HLEs sein können und dass wir 
Pädagogen nach Möglichkeiten suchen, diese Familien zu unterstützen. Die Ergebnisse zeigen aber auch, dass alle drei Gruppen im "moderaten HLE" -Bereich fielen, was zeigt, dass türkische Kindergärtner aus allen SES-Schichten durch systematische Interventionen unterstützt werden müssen.

Schlüsselwörter: frühe alphabetisierung, home alphabetisierung umwelt, sozio-ökonomischen status, kindergarten, home früh alphabetisierung umfeld fragebogen

\author{
Malaysian Abstract \\ Persekitaran Literasi Rumah Dalam Kalangan Kanak-Kanak Tadika Turki: Adakah Sosio \\ Ekonomi Membawa Perubahan?
}

Kajian ini menyiasat perbezaan yang mungkin dalam persekitaran literasi rumah (HLE) di kalangan kanak tadika Turki dari tiga SES (sosio-ekonomi) berbeza. Seramai 341 ibu bapa dan sejumlah 341 kanak-kanak tadikan daripada 24 bilik darjah tadika yang mempunyai SES rendah, sederhana dan tinggi di seluruh Ankara telah menyempurnakan borang demografi sosio ekonomi dan Home Literacy Questionnaire (HLQ). Keputusan MANOVA dan ujian Kruskal-Wallis menunjukkan perbezaan yang signifikan antara tiga tahap SES, dengan SES tinggi menunjukkan markah tinggi jauh lebih tinggi daripada SES pertengahan dan rendah dan SES pertengahan menjaringkan jauh lebih tinggi daripada SES rendah dalam semua subskala HLQ. Penemuan ini menunjukkan bahawa latar belakang SES rendah dan sederhana kanak-kanak tadika berada di dalam keadaan HLEs berkualiti dan kita sebagai pendidik perlu mencari cara-cara untuk menyokong keluarga-keluarga ini. Walau bagaimanapun keputusan juga menunjukkan bahawa ketiga-tiga kumpulan berada dalam "HLE sederhana" yang menunjukkan bahawa kanak-kanak tadika Turki dari semua strata SES mungkin perlu disokong melalui campur tangan sistematik.

Kata Kunci: literasi awal, persekitaran literasi rumah, sosio-ekonomi status, tadika, rumah awal literasi soal alam sekitar

\title{
Russian Abstract \\ Грамотность в Окружающей Среде Детского Сада в Турции: Оздают ли Разницу Социально-Экономический Статус Разница?
}

В данном исследовании исследованы возможные различия среде домашней грамотности (HLE) среди турецких студенты детского сада из трех различных социальноэкономических (SES) уровень. 341 родителей в общей сложности 341 студенты из 24 детского сада классных комнат в низких, средних и высоких окрестности СЭС по всей Анкара завершила Социально-Демографические Форма и Грамотность Главная Анкета (HLQ). Результаты MANOVA и тест Крускала-Уоллиса выявили существенные различия среди трех уровнями SES, с высоким SES забив значительно выше чем середине и низким SES и среднего SES забив значительно выше, чем низкий CЭС во всех HLQ субшкалам. Эти находя подразумевают на то, что низкие и частично средние SES детских садов могут оказаться в невыгодном для качества HLEs и поэтому мы воспитатели должны искать пути для поддержки этих семей. Однако результаты также указывают, что все три группы упали в пределах “умеренной HLE”, который показывает, что турецкие детских садов из всех SES уровень возможно должны быть поддержаны через систематические вмешательстви.

Ключевые Слова: ранняя грамотность, домашняя окружающая грамотности, социальноэкономический статус, детский сад, домой рано грамотности опросник окружение 